\title{
Ti(IV) Chloride-Promoted Diastereoselective Conjugate Addition of 1-Enoyl-5-Substituted Hydantoins with Allyltrimethylsilane
}

\author{
Jun-Ichi Yamaguchi*, Kanako Nozaki Abe, Takayuki Suyama \\ Department of Applied Chemistry, Faculty of Engineering, Kanagawa Institute of Technology, Atsugi, Japan \\ Email: *yamagu@chem.kanagawa-it.ac.jp
}

Received August 22, 2012; revised October 10, 2012; accepted October 22, 2012

\begin{abstract}
Diastereoselective conjugate addition of 1-enoyl-5-substituted hydantoins with allyltrimethylsilane in the presence of $\mathrm{Ti}(\mathrm{IV})$ chloride proceeded to give the corresponding allyl adducts in high yield and high diastereoselectivity. In order to determine the absolute configuration on the $\beta$-position of the acyl group, the hydantoin was removed by hydrolysis of the allyl adducts with a base to give the corresponding carboxylic acid. It was found that the absolute configuration was $S$ on the basis of specific rotation.
\end{abstract}

Keywords: Hydantoin; Conjugate Addition; Lewis Acid; Allyltrimethylsilane

\section{Introduction}

Chiral auxiliaries are one of the most useful tools to synthesize optically active compounds. Among the many types of chiral auxiliaries, 5-membered heterocycles containing nitrogen atom(s), such as 2-oxazolidinone or 2imidazolidinone, are the most popular [1]. Optically active hydantoins, which resemble 2-oxazolidinone or 2imidazolidinone in structure, were easily prepared from amino acid amides without racemization [2] and they play a role as a chiral auxiliary [3]. We have reported high diastereoselective conjugate addition of 1-enoyl-5-substituted hydantoin with a nucleophile, e.g., diethylaluminum chloride or dialkylcuprate reagent [3]. Generally, the diastereoselectivity at the $\beta$-position of the acyl group can be lower than that at the $\beta$-position of the acyl group (Scheme 1) $[4,5]$ in the synthesis of optically active compounds via the use of a chiral auxiliary.

Therefore, development of a new method and a new chiral auxiliary is required. In this paper, we examined Ti(IV) chloride-promoted diastereoselective conjugate addition of 1-enoyl-5-substituted hydantoins with allyltrimethylsilane and found that optically active hydantoins are effective chiral auxiliaries for inducing a chiral center at the $\beta$-position of the acyl group.

\section{Results and Discussion}

The results in the diastereoselective conjugate addition of

"Corresponding author. 1-enoyl-5-substituted hydantoins $\mathbf{1}$ with allyltrimethylsilane (All-TMS) are shown in Table 1 and Scheme 2. $\mathrm{Ti}(\mathrm{IV})$ chloride was a suitable promoter for the conjugate addition of 1a with All-TMS, but Sn(IV) chloride was not (entries 1 and 2). However, the diastereomeric excess (d.e.) of the allyl adduct 2a was not determined by ${ }^{1} \mathrm{H}$ NMR or HPLC analysis. The diastereoselectivity of 2a could be successful determined from the HPLC analysis of 3a, which was obtained from the catalytic hydrogenation of 2a (Scheme 3). Conjugate additions of 1-enoylhydantoin $\mathbf{1 b}$ and $\mathbf{1 c}$, which were prepared from Tryptophan and Valine, respectively, were also examined. Unfortunately, the d.e.s of both allyl adducts were lower (entries 3 and 4).

In addition, 1-cinnamoylhydantoin $\mathbf{1 d}$ was used as a substrate. Since the steric hindrance of the phenyl group at the cinnamoyl group is relative higher than that of the methyl group at the crotonyl group, the reactivity of $\mathbf{1 d}$ was expected to decrease relative to that of 1a. In fact, a reaction temperature of $-50^{\circ} \mathrm{C}$ was necessary to complete the reaction, however, their chemical yield and d.e. were similar (entry 5). Under the conditions of a higher reaction temperature at room temperature, the chemical yield and d.e. decreased (entry 6).

Wu et al. reported a similar conjugate addition of 1cinnamoyl-4-substituted 2-oxazolidinone with allylsilane in the presence of $\mathrm{Ti}(\mathrm{IV})$ chloride at $25^{\circ} \mathrm{C}$ [6]. However, the present conjugate addition using 1-cinnamoylhydantoin proceeded under a lower temperature of $-50^{\circ} \mathrm{C}$. Comparing the two reaction temperatures above, the re- 
Table 1. Lewis acid-promoted diastereoselective conjugate addition of 1 with All-TMS.

\begin{tabular}{cccccccccc}
\hline Entry & 1 & $\mathrm{R}^{2}$ & $\mathrm{M}$ & $\mathrm{X}$ eq. & $\mathrm{Y}$ eq. & Temp ${ }^{\circ} \mathrm{C}$ & Time h & Yield \% & d.e. \% \\
\hline 1 & $\mathrm{a}$ & $\mathrm{Me}$ & $\mathrm{Sn}$ & 1.5 & 2.5 & $\mathrm{RT}^{\mathrm{a}}$ & 24 & $\mathrm{NR}^{\mathrm{b}}$ & \\
2 & $\mathrm{a}$ & $\mathrm{Me}$ & $\mathrm{Ti}$ & 1.5 & 1.8 & -78 & 3 & 93 & $78^{\mathrm{c}}$ \\
3 & $\mathrm{~b}$ & $\mathrm{Me}$ & $\mathrm{Ti}$ & 3.0 & 3.0 & -78 & 24 & 23 & $46^{\mathrm{d}}$ \\
4 & $\mathrm{c}$ & $\mathrm{Me}$ & $\mathrm{Ti}$ & 3.0 & 3.0 & -78 & 3 & 73 & $6^{\mathrm{d}}$ \\
5 & $\mathrm{~d}$ & $\mathrm{Ph}$ & $\mathrm{Ti}$ & 4.0 & 5.0 & -50 & 24 & 92 & $82^{\mathrm{d}}$ \\
6 & $\mathrm{~d}$ & $\mathrm{Ph}$ & $\mathrm{Ti}$ & 1.5 & 1.3 & $\mathrm{RT}^{\mathrm{a}}$ & 48 & 52 & $50^{\mathrm{d}}$ \\
\hline
\end{tabular}

${ }^{\mathrm{a}} \mathrm{RT}=$ room temperature; ${ }^{\mathrm{b}} \mathrm{NR}=$ no reaction; ${ }^{\mathrm{c}}$ d.e. was determined by HPLC analysis of $\mathbf{3 a}$ which was transformed by catalytic hydrogenation of $\mathbf{2 a} ;{ }^{\mathrm{d}}$ d.e. was determined from the ${ }^{1} \mathrm{H}$ NMR spectrum.

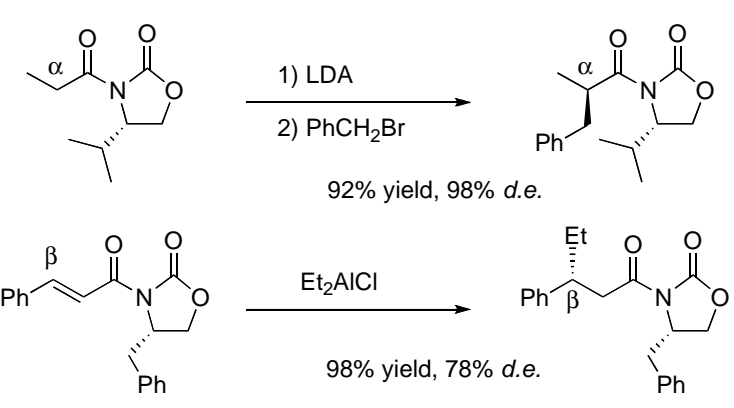

Scheme 1. Comparison of diastereoselectivities.

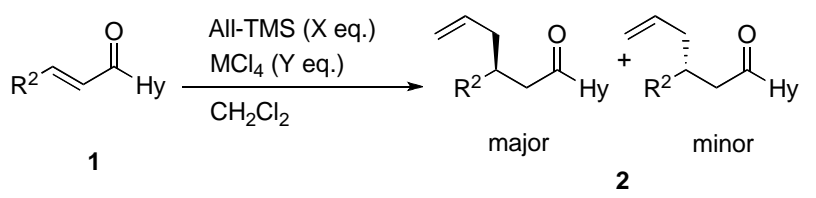

$$
\begin{array}{ll}
\text { a: } \mathrm{R}^{1}=-\mathrm{CH}_{2} \mathrm{Ph}, \mathrm{R}^{2}=\mathrm{Me} \\
\text { b: } \mathrm{R}^{1}=-\mathrm{CH}_{2}-3 \text {-indolyl, } \mathrm{R}^{2}=\mathrm{Me}
\end{array}
$$

Scheme 2. Ti(IV) chloride-promoted diastereoselective conjugate addition of 1-enoyl-5-substituted hydantoins with AllTMS.

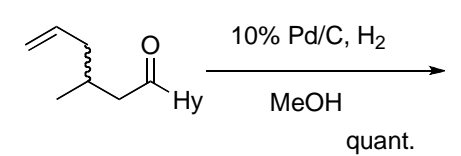

$2 a$

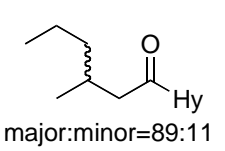

$3 a$
Scheme 3. Catalytic hydrogenation of $2 a$ to $3 a$.

activity of hydantoin would be higher than that of 2-oxazolidinone in the conjugate addition.

In order to determine the absolute configuration of the $\beta$-position of the acyl group, hydantoin was removed from the adduct to give the corresponding carboxylic acid [7]. Allin and co-workers reported that the specific rotation of $(3 R)-3$-phenyl-hex-5-enoic acid was $[\alpha]_{\mathrm{D}}^{25}$ $20.0^{\circ}\left(\mathrm{CH}_{2} \mathrm{Cl}_{2}\right)$, c 1.27) [8]. The specific rotation of $\mathbf{4}$, which was cleaved from $2 \mathbf{d}$, was $[\alpha]_{\mathrm{D}}^{25}+27.6^{\circ}\left(\mathrm{CH}_{2} \mathrm{Cl}_{2}\right.$, c 0.59). Comparison between the specific rotations, the absolute configuration of $\mathbf{4}$ was $S$ (Scheme 4 ). The above result suggested that the structure of intermediate 5 in the transition state would be a bicoordinated model, and thus allylsilane attacks the enoyl group from the $\mathrm{Si}$-face (Figure 1).

\section{Experimental}

General procedure for preparation of 1: To a DMF solution of hydantoin, acid anhydride and $\mathrm{N}, \mathrm{N}$-diisopropylethylamine was added a catalytic amount of $N, N$ dimethylaminopyridine at room temperature and the reaction mixture was stirred for over night. DMF was removed under reduced pressure and the residue was extracted with EtOAc. The organic layer was washed with $5 \%$ citric acid aq., $5 \% \mathrm{NaHCO}_{3}$ aq., and brine. The organic layer was dried with $\mathrm{Na}_{2} \mathrm{SO}_{4}$ and was concentrated under reduced pressure. The residue was purified by preparative TLC on silica-gel and $\mathbf{1}$ was given.

$(S)$-5-benzyl-1-crotonyl-3-phenylhydantoin: $\mathrm{mp} 85^{\circ} \mathrm{C}$. $[\alpha]_{\mathrm{D}}^{25}+233.7^{\circ}\left(\mathrm{CHCl}_{3}, \mathrm{c} 1.0\right) . \mathrm{IR}(\mathrm{KBr}) 1791,1733,1686$, $1639 \mathrm{~cm}^{-1}$. ${ }^{1} \mathrm{H} \mathrm{NMR}\left(\mathrm{CDCl}_{3}, 400 \mathrm{MHz}\right) \delta 1.98(3 \mathrm{H}, \mathrm{dd}, \mathrm{J}$ $=1.4$ and $6.4 \mathrm{~Hz}), 3.35(1 \mathrm{H}, \mathrm{dd}, \mathrm{J}=2.3$ and $13.7 \mathrm{~Hz})$, $3.67(1 \mathrm{H}, \mathrm{dd}, \mathrm{J}=5.0$ and $13.7 \mathrm{~Hz}), 5.02(1 \mathrm{H}, \mathrm{dd}, \mathrm{J}=2.3$ and 5.0 Hz), 6.84-6.90 (2H, m), $7.02-7.10(2 \mathrm{H}, \mathrm{m}), 7.13$ - $7.40(8 \mathrm{H}, \mathrm{m}) .{ }^{13} \mathrm{C} \mathrm{NMR}\left(\mathrm{CDCl}_{3}, 400 \mathrm{MHz}\right) \delta 18.63$, $34.80,59.58,123.12,126.44,127.67,128.61,128.92$, $129.10,129.78,130.25,133.37,147.72,152.43,164.20$, 169.65 .

(S)-1-crotonyl-5-(3-indolylmethyl)-3-phenylhydantoin: $\operatorname{mp~} 85^{\circ} \mathrm{C} .[\alpha]_{\mathrm{D}}^{25}+172.3^{\circ}\left(\mathrm{CHCl}_{3}, \mathrm{c} 1.0\right)$. IR (KBr) 1791 , $1731,1684,1635 \mathrm{~cm}^{-1} .{ }^{1} \mathrm{H}$ NMR $\left(\mathrm{CDCl}_{3}, 400 \mathrm{MHz}\right) \delta$ $1.97(3 \mathrm{H}, \mathrm{dd}, \mathrm{J}=1.8$ and $6.9 \mathrm{~Hz}), 3.62(1 \mathrm{H}, \mathrm{dd}, \mathrm{J}=2.3$ and $14.7 \mathrm{~Hz}), 3.85(1 \mathrm{H}, \mathrm{dd}, \mathrm{J}=5.0$ and $14.7 \mathrm{~Hz}), 5.03$ $(1 \mathrm{H}, \mathrm{dd}, \mathrm{J}=2.3$ and $5.0 \mathrm{~Hz}), 6.55-6.65(2 \mathrm{H}, \mathrm{m}), 6.89$ $(1 \mathrm{H}, \mathrm{s}), 7.05(1 \mathrm{H}, \mathrm{dt}, \mathrm{J}=0.9$ and 8.2$), 7.10-7.20(2 \mathrm{H}, \mathrm{m})$, $7.20-7.35(5 \mathrm{H}, \mathrm{m}), 7.51(1 \mathrm{H}, \mathrm{dd}, \mathrm{J}=0.9$ and $8.2 \mathrm{~Hz})$, $8.31(1 \mathrm{H}, \mathrm{s}) .{ }^{13} \mathrm{C} \mathrm{NMR}\left(\mathrm{CDCl}_{3}, 400 \mathrm{MHz}\right) \delta 18.62,25.27$, 59.59, 107.64, 111.05, 119.20, 120.03, 122.42, 123.39, 


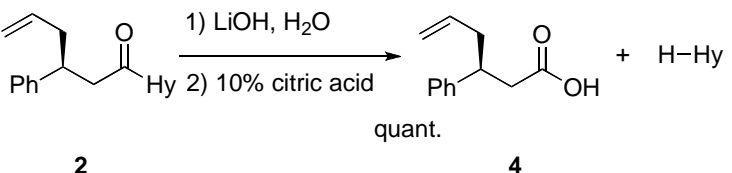

Scheme 4. Hydrolysis of 2 to carboxylic acid 4 and hydantoin.

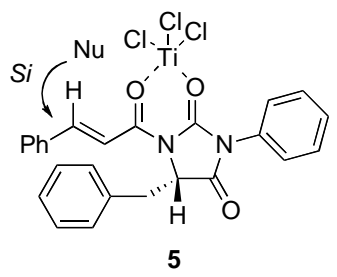

Figure 1. Conformation of intermediate 5 in the transition state.

$123.75,126.44,127.36,128.77,128.97,130.27,135.89$, 147.33, 152.70, 164.32, 170.58 .

(S)-1-crotonyl-5-isopropyl-3-phenylhydantoin: oil. $[\alpha]_{\mathrm{D}}^{25}$ $+19.7^{\circ}\left(\mathrm{CHCl}_{3}, \mathrm{c} 0.27\right)$. IR (neat) 1790, 1732, 1688, $1637 \mathrm{~cm}^{-1}$. ${ }^{1} \mathrm{H}$ NMR $\left(\mathrm{CDCl}_{3}, 400 \mathrm{MHz}\right) \delta 0.97(3 \mathrm{H}, \mathrm{d}, \mathrm{J}$ $=6.9 \mathrm{~Hz}), 1.26(3 \mathrm{H}, \mathrm{d}, \mathrm{J}=6.9 \mathrm{~Hz}), 1.97(3 \mathrm{H}, \mathrm{dd}, \mathrm{J}=6.4$ and $0.9 \mathrm{~Hz}), 2.66(1 \mathrm{H}$, dsept, $\mathrm{J}=6.9$ and $3.2 \mathrm{~Hz}), 4.70$ $(1 \mathrm{H}, \mathrm{d}, \mathrm{J}=3.2 \mathrm{~Hz}), 7.20(1 \mathrm{H}, \mathrm{dq}, \mathrm{J}=15.1$ and $6.4 \mathrm{~Hz})$, $7.30(1 \mathrm{H}, \mathrm{dq}, \mathrm{J}=15.1$ and $0.9 \mathrm{~Hz}), 7.33(2 \mathrm{H}, \mathrm{dt}, \mathrm{J}=7.3$ and $2.7 \mathrm{~Hz}), 7.41(1 \mathrm{H}, \mathrm{dt}, \mathrm{J}=7.3$ and $2.3 \mathrm{~Hz}), 7.48(2 \mathrm{H}$, $\mathrm{tt}, \mathrm{J}=7.3$ and $2.3 \mathrm{~Hz}) .{ }^{13} \mathrm{C} \mathrm{NMR}\left(\mathrm{CDCl}_{3}, 400 \mathrm{MHz}\right) \delta$ 15.64, 18.06, 18.58, 29.70, 63.02, 123.41, 126.47, 128.90, $129.22,130.60,147.39,153.10,164.07,169.32$.

(S)-5-benzyl-1-cinnnamoyl-3-phenylhydantoin: $\mathrm{mp} 129^{\circ} \mathrm{C}$ - $130^{\circ}$ C. $[\alpha]_{\mathrm{D}}^{25}+233.7^{\circ}\left(\mathrm{CHCl}_{3}, \mathrm{c} 1.0\right)$. IR (KBr) 1786 , $1726,1679,1618 \mathrm{~cm}^{-1}$. ${ }^{1} \mathrm{H}$ NMR $\left(\mathrm{CDCl}_{3}, 400 \mathrm{MHz}\right) \delta$ $3.40(1 \mathrm{H}, \mathrm{dd}, \mathrm{J}=2.8$ and $13.7 \mathrm{~Hz}), 3.74(1 \mathrm{H}, \mathrm{dd}, \mathrm{J}=5.0$ and $13.7 \mathrm{~Hz}), 5.11(1 \mathrm{H}, \mathrm{dd}, \mathrm{J}=2.8$ and $5.0 \mathrm{~Hz}), 6.85-$ $6.95(2 \mathrm{H}, \mathrm{m}), 7.05-7.15(2 \mathrm{H}, \mathrm{m}), 7.25-7.30(3 \mathrm{H}, \mathrm{m})$, $7.35-7.45(6 \mathrm{H}, \mathrm{m}), 7.60-7.65(2 \mathrm{H}, \mathrm{m}), 7.88(1 \mathrm{H}, \mathrm{d}, \mathrm{J}=$ $16.0 \mathrm{~Hz}), 8.00(1 \mathrm{H}, \mathrm{d}, \mathrm{J}=16.0 \mathrm{~Hz}) .{ }^{13} \mathrm{C} \mathrm{NMR}\left(\mathrm{CDCl}_{3}\right.$, $400 \mathrm{MHz}) \delta 34.91,59.82,118.20,126.52,27.77,128.69$, $128.72,128.93,129.07,129.22,129.87,130.27,130.91$, $133.38,134.41,147.13,152.69,164.51,169.66$.

General procedure for conjugate addition of 1 with All-TMS: To a $\mathrm{CH}_{2} \mathrm{Cl}_{2}$ solution of 1 was added $\mathrm{Ti}(\mathrm{IV})$ chloride under nitrogen. The mixture was stirred for 10 min. All-TMS was added to the reaction mixture. The reaction was quenched by adding saturated $\mathrm{NH}_{4} \mathrm{Cl}$ solution, and the organic materials were extracted with $\mathrm{CH}_{2} \mathrm{Cl}_{2}$. The $\mathrm{CH}_{2} \mathrm{Cl}_{2}$ layer was washed with brine, and dried over $\mathrm{Na}_{2} \mathrm{SO}_{4}$. After removal of solvent under reduced pressure, the residue was purified by silica-gel column chromatography, and the allyl adduct was isolated.

Allyl adduct 2a (signals of the major adduct were showed only): ${ }^{1} \mathrm{H} \mathrm{NMR}\left(\mathrm{CDCl}_{3}, 300 \mathrm{MHz}\right) \delta 1.03(3 \mathrm{H}, \mathrm{d}$, $\mathrm{J}=7.2 \mathrm{~Hz}), 2.05-2.25$ (3H, m), $2.79(1 \mathrm{H}, \mathrm{dd}, \mathrm{J}=16.7$ and $7.5 \mathrm{~Hz}), 2.93(1 \mathrm{H}, \mathrm{dd}, \mathrm{J}=16.7$ and $5.1 \mathrm{~Hz}), 3.37(1 \mathrm{H}$, $\mathrm{dd}, \mathrm{J}=13.9$ and $2.7 \mathrm{~Hz}), 3.66(1 \mathrm{H}, \mathrm{dd}, \mathrm{J}=13.9$ and 5.1 $\mathrm{Hz}), 4.95$ - $5.10(3 \mathrm{H}, \mathrm{m}), 5.70-5.90(1 \mathrm{H}, \mathrm{m}), 6.85-6.95$ (2H, m), 7.05 - $7.10(2 \mathrm{H}, \mathrm{m}), 7.20-7.45(6 \mathrm{H}, \mathrm{m})$.

Allyl adduct 2b: ${ }^{1} \mathrm{H}$ NMR $\left(\mathrm{CDCl}_{3}, 400 \mathrm{MHz}\right) \delta 1.03$ $(2.19 \mathrm{H}, \mathrm{d}, \mathrm{J}=6.4 \mathrm{~Hz}$, the major adduct signal), 1.07 $(0.81 \mathrm{H}, \mathrm{d}, \mathrm{J}=6.9 \mathrm{~Hz}$, the minor adduct signal), 2.00 $2.30(3 \mathrm{H}, \mathrm{m}), 2.64(0.27 \mathrm{H}, \mathrm{dd}, \mathrm{J}=16.9$ and $7.3 \mathrm{~Hz}$, the minor adduct signal), $2.79(0.73 \mathrm{H}, \mathrm{dd}, \mathrm{J}=16.9$ and 6.4 $\mathrm{Hz}$, the major adduct signal), $2.84(0.73 \mathrm{H}, \mathrm{dd}, \mathrm{J}=16.9$ and $6.9 \mathrm{~Hz}$, the major adduct signal $), 2.99(0.27 \mathrm{H}$, dd, $\mathrm{J}=$ 16.9 and $5.5 \mathrm{~Hz}$, the minor adduct signal), 3.59 (1H, dd, $\mathrm{J}$ $=14.2$ and $2.3 \mathrm{~Hz}), 3.85(1 \mathrm{H}, \mathrm{dd}, \mathrm{J}=14.2$ and $5.0 \mathrm{~Hz})$, $5.00-5.10(3 \mathrm{H}, \mathrm{m}), 5.70-5.90(1 \mathrm{H}, \mathrm{m}), 6.50-6.60(2 \mathrm{H}$, $\mathrm{m}), 6.92(1 \mathrm{H}, \mathrm{d}, \mathrm{J}=2.8 \mathrm{~Hz}), 7.07(1 \mathrm{H}, \mathrm{td}, \mathrm{J}=6.9$ and 0.9 $\mathrm{Hz}), 7.19(1 \mathrm{H}, \mathrm{td}, \mathrm{J}=8.2$ and $0.9 \mathrm{~Hz}), 7.25-7.30(3 \mathrm{H}$, m), $7.33(1 \mathrm{H}, \mathrm{d}, \mathrm{J}=8.2 \mathrm{~Hz}), 7.50(1 \mathrm{H}, \mathrm{d}, \mathrm{J}=8.2 \mathrm{~Hz})$, $8.10(1 \mathrm{H}, \mathrm{s})$.

Allyl adduct 2c: ${ }^{1} \mathrm{H}$ NMR $\left(\mathrm{CDCl}_{3}, 400 \mathrm{MHz}\right) \delta 0.95-$ $1.05(3 \mathrm{H}, \mathrm{m}), 1.25(3 \mathrm{H}, \mathrm{d}, \mathrm{J}=6.9 \mathrm{~Hz}), 1.95-2.30(3 \mathrm{H}$, $\mathrm{m}), 2.55-2.65(1 \mathrm{H}, \mathrm{m}), 2.71(1 \mathrm{H}, \mathrm{dd}, \mathrm{J}=16.0$ and 8.2 $\mathrm{Hz}$, the minor adduct signal), $2.92(1 \mathrm{H}, \mathrm{dd}, \mathrm{J}=16.0$ and $6.4 \mathrm{~Hz}$, the major adduct signal), $2.96(1 \mathrm{H}, \mathrm{dd}, \mathrm{J}=16.0$ and $7.3 \mathrm{~Hz}$, the major adduct signal), $3.14(1 \mathrm{H}$, dd, $\mathrm{J}=$ 16.0 and $5.0 \mathrm{~Hz}$, the minor adduct signal), $4.65(1 \mathrm{H}, \mathrm{d}, \mathrm{J}$ $=3.2 \mathrm{~Hz}), 4.95-5.10(2 \mathrm{H}, \mathrm{m}), 5.70-5.85(1 \mathrm{H}, \mathrm{m}), 7.30$ - $7.35(2 \mathrm{H}, \mathrm{m}), 7.30-7.35(3 \mathrm{H}, \mathrm{m})$.

Allyl adduct 2d: ${ }^{1} \mathrm{H}$ NMR $\left(\mathrm{CDCl}_{3}, 400 \mathrm{MHz}\right) \delta 2.47$ $(2 \mathrm{H}, \mathrm{t}, \mathrm{J}=6.9 \mathrm{~Hz}), 3.17(1 \mathrm{H}, \mathrm{dd}, \mathrm{J}=16.5$ and $5.0 \mathrm{~Hz})$, $3.29(1 \mathrm{H}, \mathrm{dd}, \mathrm{J}=13.7$ and $2.8 \mathrm{~Hz}), 3.35-3.50(1 \mathrm{H}, \mathrm{m})$, $3.51(1 \mathrm{H}, \mathrm{dd}, \mathrm{J}=16.5$ and $8.7 \mathrm{~Hz}), 3.59(1 \mathrm{H}, \mathrm{dd}, \mathrm{J}=13.7$ and $5.0 \mathrm{~Hz}), 4.79(0.91 \mathrm{H}, \mathrm{dd}, \mathrm{J}=5.0$ and $2.5 \mathrm{~Hz}), 4.88$ $(0.09 \mathrm{H}, \mathrm{dd}, \mathrm{J}=5.0$ and $2.3 \mathrm{~Hz}), 4.95-5.10(2 \mathrm{H}, \mathrm{m}), 5.65$ - $5.80(1 \mathrm{H}, \mathrm{m}), 6.57(0.18 \mathrm{H}, \mathrm{d}, \mathrm{J}=6.9 \mathrm{~Hz}), 6.80-6.85$ $(1.82 \mathrm{H}, \mathrm{m}), 6.95-7.05(1.82 \mathrm{H}, \mathrm{m}), 7.09(0.18 \mathrm{H}, \mathrm{t}, \mathrm{J}=$ $7.3 \mathrm{~Hz}), 7.15-7.40(11 \mathrm{H}, \mathrm{m})$.

Catalytic hydrogenation of 2a: To a methanol (80 $\mathrm{mL}$ ) and a small amount of $\mathrm{CH}_{2} \mathrm{Cl}_{2}$ solution of $2 \mathbf{a}$ was added $10 \% \mathrm{Pd} / \mathrm{C}$ as catalyst under hydrogen, and the reaction mixture was stirred for 2 days. After removal of the catalyst by Celite filtration, the organic layer was concentrated under reduced pressure and 3a was given.

3a (signals of the major adduct were showed only): ${ }^{1} \mathrm{H}$ NMR $\left(\mathrm{CDCl}_{3}, 300 \mathrm{MHz}\right) \delta 0.93(3 \mathrm{H}, \mathrm{t}, \mathrm{J}=6.6 \mathrm{~Hz}), 1.02$ $(3 \mathrm{H}, \mathrm{d}, \mathrm{J}=6.6 \mathrm{~Hz}), 1.25-1.45(4 \mathrm{H}, \mathrm{m}), 2.00-2.10(1 \mathrm{H}$, $\mathrm{m}), 2.75(1 \mathrm{H}, \mathrm{dd}, \mathrm{J}=16.4$ and $8.1 \mathrm{~Hz}), 2.93(1 \mathrm{H}, \mathrm{dd}, \mathrm{J}=$ 16.4 and $5.4 \mathrm{~Hz}), 3.37(1 \mathrm{H}, \mathrm{dd}, \mathrm{J}=13.9$ and $2.7 \mathrm{~Hz})$, $3.66(1 \mathrm{H}, \mathrm{dd}, \mathrm{J}=13.9$ and $4.9 \mathrm{~Hz}), 4.79(1 \mathrm{H}, \mathrm{dd}, \mathrm{J}=4.9$ and $2.7 \mathrm{~Hz}), 6.85-6.95(2 \mathrm{H}, \mathrm{m}), 7.05-7.10(2 \mathrm{H}, \mathrm{m})$, $7.25-7.40(6 \mathrm{H}, \mathrm{m})$.

Hydrolysis of the allyl adduct into 4 [7]: To a solution of $\mathrm{LiOH}$ and $\mathrm{H}_{2} \mathrm{O}_{2}$ was added a solution (THF and $\mathrm{H}_{2} \mathrm{O}$ ) of 4 at $0^{\circ} \mathrm{C}$. The reaction mixture was stirred for $2 \mathrm{~h}$. $\mathrm{Na}_{2} \mathrm{SO}_{3}$ was added to the reaction mixture at $0^{\circ} \mathrm{C}$, and it 
was stirred for $30 \mathrm{~min}$. After removal of the solvent under reduced pressure, the residue was aciditified by adding $10 \%$ citric acid solution. The organic materials were extracted with $\mathrm{CH}_{2} \mathrm{Cl}_{2}$. The organic layer was dried over $\mathrm{Na}_{2} \mathrm{SO}_{4}$. The solvent was removed under reduced pressure, and the residue was purified by silica-gel preparative TLC and $\mathbf{4}$ was obtained as oil.

4: ${ }^{1} \mathrm{H}$ NMR $\left(\mathrm{CDCl}_{3}, 400 \mathrm{MHz}\right) \delta 2.37(2 \mathrm{H}, \mathrm{t}, \mathrm{J}=7.3$ $\mathrm{Hz}), 2.57(1 \mathrm{H}, \mathrm{dd}, \mathrm{J}=16.0$ and $8.2 \mathrm{~Hz}), 2.69(1 \mathrm{H}, \mathrm{dd}, \mathrm{J}=$ 16.0 and $6.4 \mathrm{~Hz}), 3.17(1 \mathrm{H}$, quint, $\mathrm{J}=7.3 \mathrm{~Hz}), 4.90-5.05$ $(2 \mathrm{H}, \mathrm{m}), 5.63(1 \mathrm{H}, \mathrm{ddt}, \mathrm{J}=16.9,10.0$, and $7.3 \mathrm{~Hz}), 7.10$ $7.30(5 \mathrm{H}, \mathrm{m}), 8.65(1 \mathrm{H}, \mathrm{brs})$.

\section{Conclusion}

We showed that hydantoin is more reactive than conventional 2-oxazolidinone chiral auxiliaries. Further studies on the utilizations of hydantoin as a unique chiral auxiliary are now in progress.

\section{REFERENCES}

[1] R. M. Coates and S. E. Denmark, "Handbook of Reagents for Organic Synthesis: Reagents, Auxiliaries, and Catalysts for C-C Bond Formation," John Willey \& Sons Ltd., Chichester, 1999.

[2] J. Yamaguchi, M. Harada, T. Kondo, T. Noda and T. Suyama, "A Facile Method for Preparation of Optically Active Hydantoin," Chemistry Letters, Vol. 32, No. 4, 2003, pp. 372-373. doi:10.1246/c1.2003.372
[3] J. Yamaguchi, M. Harada, T. Narushima, A. Saitoh, K. Nozaki and T. Suyama, "Diastereoselective Conjugate Addition of 1-( $\alpha, \beta$-Unsaturated acyl)hydantoin with Nucleophiles," Tetrahedron Letters, Vol. 46, No. 38, 2005, pp. 6411-6415. doi:10.1016/j.tetlet.2005.07.116

[4] D. A. Evans, M. D. Ennis and D. J. Mathre, "Asymmetric Alkylation Reaction of Chiral Imide Enolate. A Practical Approach to the Enantioselective Synthesis of $\alpha$-Substituted Carboxylic Acid Derivatives," Journal of the American Chemical Society, Vol. 104, No. 6, 1982, pp. 17371739. doi:10.1021/ja00370a050

[5] K. Rück and H. Kunz, "Stereoselective Conjugate Addition of Organoaluminum Chloride to $\alpha, \beta$-Unsaturated Carboxylic Acid Derivatives," Synthesis, Vol. 1993, No. 10, 1993, pp. 1018-1028. doi:10.1055/s-1993-25990

[6] M.-J. Wu, C.-C. Wu and P.-C. Lee, "Lewis Acid Promoted Asymmetric 1,4-Addition of Allyltrimethylsilane to Chiral $\alpha, \beta$-Unsaturated $N$-Acylamides," Tetrahedron Letters, Vol. 33, No. 18, 1992, pp. 2547-2548. doi:10.1016/S0040-4039(00)92238-X

[7] J. R. Harding, R. A. Hughes, N. M. Kelly, A. Sutherland and C. L. Willis, "Synthesis of Isotopically Labelled L-aAmino Acid with an Asymmetric Centre at C-3," Journal of the Chemical Society, Perkin Transactions 1, Vol. 2000, 2000, pp. 3406-3416. doi:10.1039/b0051721

[8] S. M. Allin, M. S. Essat, C. H. Pita, R. D. Baird, V. McKee, M. Elsegood, M. Edgar, D. M. Andrews, P. Shah and I. Aspinall, "Applications of the Amino-Cope Rearrengement: Synthesis of Tetrahydropyran, d-Lactone and Piperidine Targets," Organic \& Biomolecular Chemistry, Vol. 3, 2005, pp. 809-815. doi:10.1039/b416179c 